\title{
The effect of dietary protein deficiency on transport of vitamin $A$ in the blood and its storage in the liver
}

\author{
By C. J. FRIEND, C. R. C. HEARD, B. S. PLATT, R. J. C. STEWART \\ AND M. R. TURNER \\ Human Nutrition Research Unit, National Institute for Medical Research, \\ Mill Hill, London, N.W. 7
}

\section{(Received 5 September 1960-Revised 29 December 1960)}

Signs of vitamin A deficiency may be among those of malnutrition in areas where the dietary intake of vitamin $A$ is not unduly low. In the normal animal vitamin $A$ is efficiently absorbed, but oil or fat is essential, and the more unsaturated the fat the better the absorption. Bile acids and pancreatic lipase are also needed, and, as pathological changes in the liver and pancreas are found in malnutrition, it is not surprising that the low levels of vitamin A found in blood in malnourished subjects have been regarded as secondary to absorption defects. Some clinical evidence has been offered in support of this view. Trowell, Moore \& Sharman (1954) found serum carotenoid concentrations to be lower in patients with kwashiorkor than in healthy adults and infants. Arroyave, Viteri, Béhar \& Scrimshaw (1959) obtained similar results for vitamin $A$ : they also published a figure showing that in malnourished children there was no response to dosage with vitamin A palmitate but that after treatment for 5 days with skim-milk powder a normal response was obtained.

Later, Arroyave, Béhar, Wilson, Mendez \& Scrimshaw (1959) had doubts about the exclusive importance of absorption; they found that when children entered hospital with low serum levels but with 'significant reserves of liver vitamin $A$ ' the reserves were apparently 'liberated' into the blood stream after about ro days' treatment with skim-milk powder. This observation suggests that a factor other than lack of vitamin A is involved, for, in uncomplicated vitamin A deficiency, serum levels of the vitamin do not fall significantly until liver reserves are almost exhausted, and recover only when the vitamin or its precursor, carotene, is given.

It has been recognized for many years that vitamin $A$ is transported from the liver to its site of action as part of a water-soluble protein complex. Pett \& LePage (I940) believed the carrier to be a globulin, whereas Dzialoszynski, Mystkowski \& Stewart (1945), on the basis of ammonium-sulphate separations, believed albumin to be involved. Krinsky, Cornwell \& Oncley (1958) isolated serum albumin by two different techniques and, as neither sample contained a significant amount of the vitamin, came to the conclusion that albumin was not the carrier. Recently Garbers, Gillman \& Peisach (1960), using radioactive vitamin A, have suggested $\alpha_{1}$-globulin as the main protein fraction concerned in the transport of vitamin $\mathrm{A}$ alcohol.

Since the vitamin is transported as part of a protein complex, low serum vitamin $A$ levels might be expected in malnourished subjects if the levels of the protein carrier 
were reduced. Heard, Platt \& Stewart (1958) produced, in pigs, syndromes similar to marasmus and kwashiorkor in man. Since these animals exhibit marked alterations in serum protein concentrations, they presented an opportunity to evaluate the relative importance of dietary intake, absorption or liver stores of vitamin A and of insufficiency of protein carrier in producing the low concentration of serum vitamin A found in malnourished subjects. A preliminary report of this work has indicated the main finding of a very close correlation between serum vitamin A levels and the concentration of serum 'albumin' (Friend, Heard, Platt, Stewart \& 'Turner, I960).

\section{EXPERIMENTAL}

\section{Animals and diet}

Pigs removed from the sow at about 5 days of age were given a commercial weaning diet. Each animal received an injection of $2 \mathrm{ml}$ Imferon (Benger Laboratories Ltd) (containing $50 \mathrm{mg}$ iron $/ \mathrm{ml}$ ) and, to control scouring, a course of Stromez (Imperial Chemical Industries Ltd) (sulphadimidine 10\%, streptomycin sulphate $2 \%$, light kaolin $86 \%$ ). They were transferred to the experimental diet when they reached a weight of $3 \mathrm{~kg}$, which usually occurred after about 2 weeks on the commercial diet.

Table I. Percentage composition of basal diets and dietary supplements given to pigs

\section{Ingredient}

Whole-wheat flour

Cooked haricot beans

Lucerne meal

de Loureiro's (1931) salt

mixture

Chromic oxide

Arachis oil + ergocalciferol

(50 i.u./g)

Maize starch

Casein

Vitamin supplement

per $100 \mathrm{~g}$ diet*
Diet

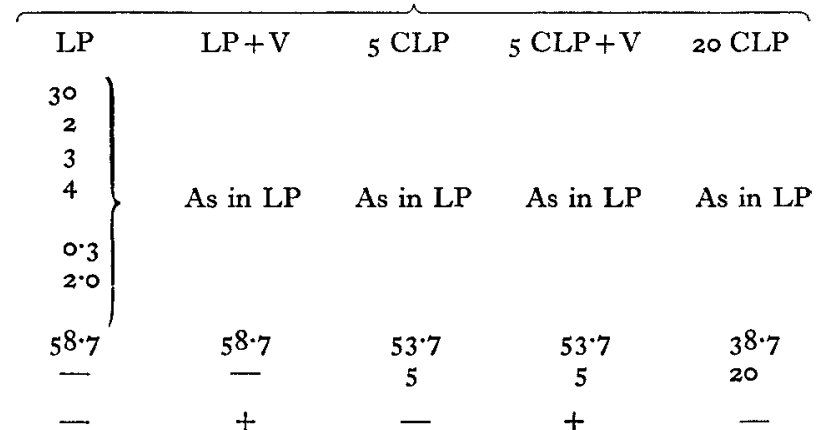

* Thiamine hydrochloride $0.22 \mathrm{mg}$, riboflavin $0.33 \mathrm{mg}$, calcium pantothenate $2.22 \mathrm{mg}$, nicotinic acid $3.33 \mathrm{mg}$, pyridoxine hydrochloride $0.55 \mathrm{mg}$, choline hydrochloride roo.0 $\mathrm{mg}$, cyanocobalamin $2.2 \mu \mathrm{g}$, biotin $5.0 \mu \mathrm{g}$. Additional calcium $(0.65 \mathrm{~g})$ as $\mathrm{CaCO}_{3}$ was also included in these diets.

The pigs were housed indoors in individual pens with wire-mesh floors. The experimental diets, the compositions of which are shown in Table I, were a lowprotein diet (LP), a low-protein diet supplemented with carbohydrate $(\mathrm{LP}+\mathrm{CH})$, diets (5 CLP and $20 \mathrm{CLP}$ ) in which casein $(5$ or $20 \%, \mathrm{w} / \mathrm{w})$ replaced starch in the $\mathrm{LP}$ diet, and $\mathrm{LP}, \mathrm{LP}+\mathrm{CH}$ and $5 \mathrm{CLP}$ diets supplemented with $\mathrm{B}$ vitamins $(\mathrm{LP}+\mathrm{V}, \mathrm{LP}+\mathrm{CH}+\mathrm{V}$ and $5 \mathrm{CLP}+\mathrm{V})$. One animal received the $5 \mathrm{CLP}$ diet supplemented with carbohydrate $(5 \mathrm{CLP}+\mathrm{CH})$. The control animals were fed on a commercial diet (NI) (Amvilac, Glaxo Laboratories Ltd). Two pigs received a thiaminedeficient diet $\left(-B_{1}\right)$ composed of casein, dried-meat powder, starch, glucose and the 
thiamine-free B-vitamin mixture; vitamins $\mathrm{A}, \mathrm{D}, \mathrm{K}$, and $\mathrm{E}$ were supplied in arachis oil. The protein and carotenoid contents of all experimental diets are shown in Table 2. Although, in the later stages of the experiment, the animals on the $\mathrm{LP}, \mathrm{LP}+\mathrm{CH}$ and $-B_{1}$ diets refused some of the food offered, they were still receiving adequate amounts of vitamin $A$ or carotenoids. When it was desired to increase the protein intake, the $20 \mathrm{CLP}$ or Nl diet was substituted for the LP or LP $+\mathrm{CH}$ diet.

A single dose of vitamin A ester was given to each of five pigs (roo0oo i.u. to one and 200000 i.u. to four); it was mixed with a small quantity of the food and then offered to the animals to ensure $(a)$ that it would all be consumed and $(b)$ that it would be available during the absorption of other foodstuffs.

Table 2. Protein and carotenoids in the daily diet of a pig

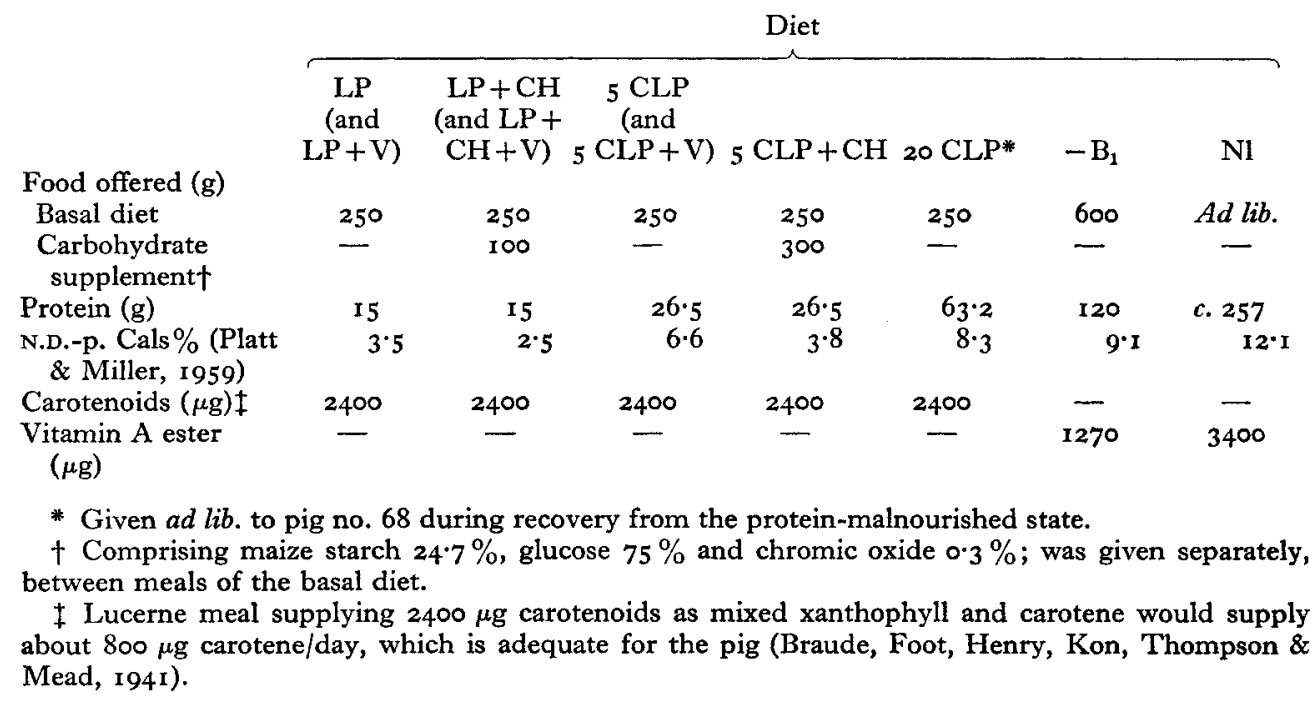

\section{Procedure}

Blood samples were collected after an $18 \mathrm{~h}$ fast. Blood was obtained from an ear vein or, when the animal was to be killed, from the heart under thiopentone-sodium (May \& Baker Ltd) anaesthesia. The serum was separated and stored at $-20^{\circ}$. The liver samples were obtained at post-mortem and were frozen immediately on dry ice and stored at $-20^{\circ}$.

Serum proteins were determined by electrophoresis performed on strips of Whatman 3 MM filter-paper in Shandon horizontal tanks (Shandon Scientific Company Ltd, London), with a barbitone buffer of $\mathrm{pH} 8.6$, ionic strength 0.05 , with a potential gradient of $2.25 \mathrm{~V} / \mathrm{cm}$ for $18 \mathrm{~h}$. The strips were oven-dried at $110^{\circ}$, stained with bromophenol blue and the fractions determined after elution (Hardwicke, 1954). The total nitrogen was determined by a semi-micro-Kjeldahl method.

As the carotenoid content of pig's blood is negligible, only the vitamin A was estimated. The method used for serum samples was similar to Yudkin's (I94I) modification of Kimble's (1939) method, and was little different from that used by the 
Cambridge team in the investigation of Hume \& Krebs (1949) on vitamin A requirements of human adults. Great care was taken when adding the ethanol to the serum to ensure that the ampoules were well shaken after the addition of each drop. The ampoules were sealed after addition of light petroleum and again well shaken. Portions of the light-petroleum extract were used for estimation of the vitamin. Samples of liver were homogenized in a Waring Blendor with water and alcohol and the denatured protein was extracted with light petroleum as for the serum.

\section{RESULTS}

The vitamin A content of the livers and the vitamin A and 'albumin' concentration in the serum of pigs on the various diets are shown in Table 3 . In litters $I, 2$ and 4 , in which litter-mates received different levels of dietary protein, it is apparent that serum 'albumin' levels reflect the degree of dietary protein insufficiency.

Pigs receiving the CLP diet had serum vitamin A levels within the normal range, which suggests that the dietary supply of carotenoids was adequate. Pigs receiving the $\mathrm{LP}$ and $\mathrm{LP}+\mathrm{CH}$ diets, with the same amount and form of carotenoids as supplied by the CLP diet, had low serum levels of vitamin A. This might be accepted as evidence of poor absorption of carotenoids and of vitamin $A$ in the more severely proteindeficient animals, and the fact that in these pigs oral dosage with $\beta$-carotene in oil did not raise the serum vitamin A levels would support this view. Thompson, Braude, Coates, Cowie, Ganguly \& Kon (1950) have shown, however, that pigs do not absorb $\beta$-carotene as such, but first convert it into vitamin A. It was possible, therefore, that the low serum levels of the vitamin might be due to an inability to convert carotene rather than to a defect in absorption. Two of the protein-deficient pigs (nos. 87 and 94) were therefore given large single doses of vitamin A ester (200000 i.u.) and the blood level was checked daily for 3 days, but without evidence of a significant rise. Normal animals given similar test doses showed a definite increase in serum vitamin $\mathrm{A}$ for at least $24 \mathrm{~h}$.

Although neither $\beta$-carotene nor vitamin A was capable of raising the level of vitamin $A$ in the serum of protein-deficient animals, at post-mortem it was found that the concentration of vitamin $A$ in the livers of the malnourished animals given the test doses was about five times as high as in the undosed litter-mates on the same diet. The extra storage of vitamin A in the liver accounted for about $20 \%$ of the test dose in the malnourished pigs and over $80 \%$ in the normal animals.

Attempts by other workers to find a correlation between vitamin $A$ in the liver and serum have been unfruitful. Glover, Goodwin \& Morton (1947) claimed that a correlation could be found between the liver vitamin $A$ alcohol fraction and circulating vitamin A, but Ganguly \& Krinsky (1953) could not confirm it. In the present work no correlation could be found between the liver stores and vitamin $A$ in the blood (Fig. I). No attempt was made to estimate vitamin A ester and alcohol separately.

However, a highly significant correlation $(r=0.76 ; P<0.001)$ was found between the concentration of serum vitamin A and that of serum 'albumin' (Fig. 2).

Pig no. 97 (litter 4) had been maintained on a diet deficient in thiamine, with ample 
supplies of both protein and vitamin A ester, but, as is usual with animals on thiaminedeficient diets, the appetite was poor and the concentration of vitamin $\mathrm{A}$ in the liver was rather low, and was the same as that of pig no. $93(\mathrm{LP}+\mathrm{CH}$; litter 4$)$. Although

Table 3. Vitamin $A$ in liver and vitamin $A$ and 'albumin' in serum of pigs

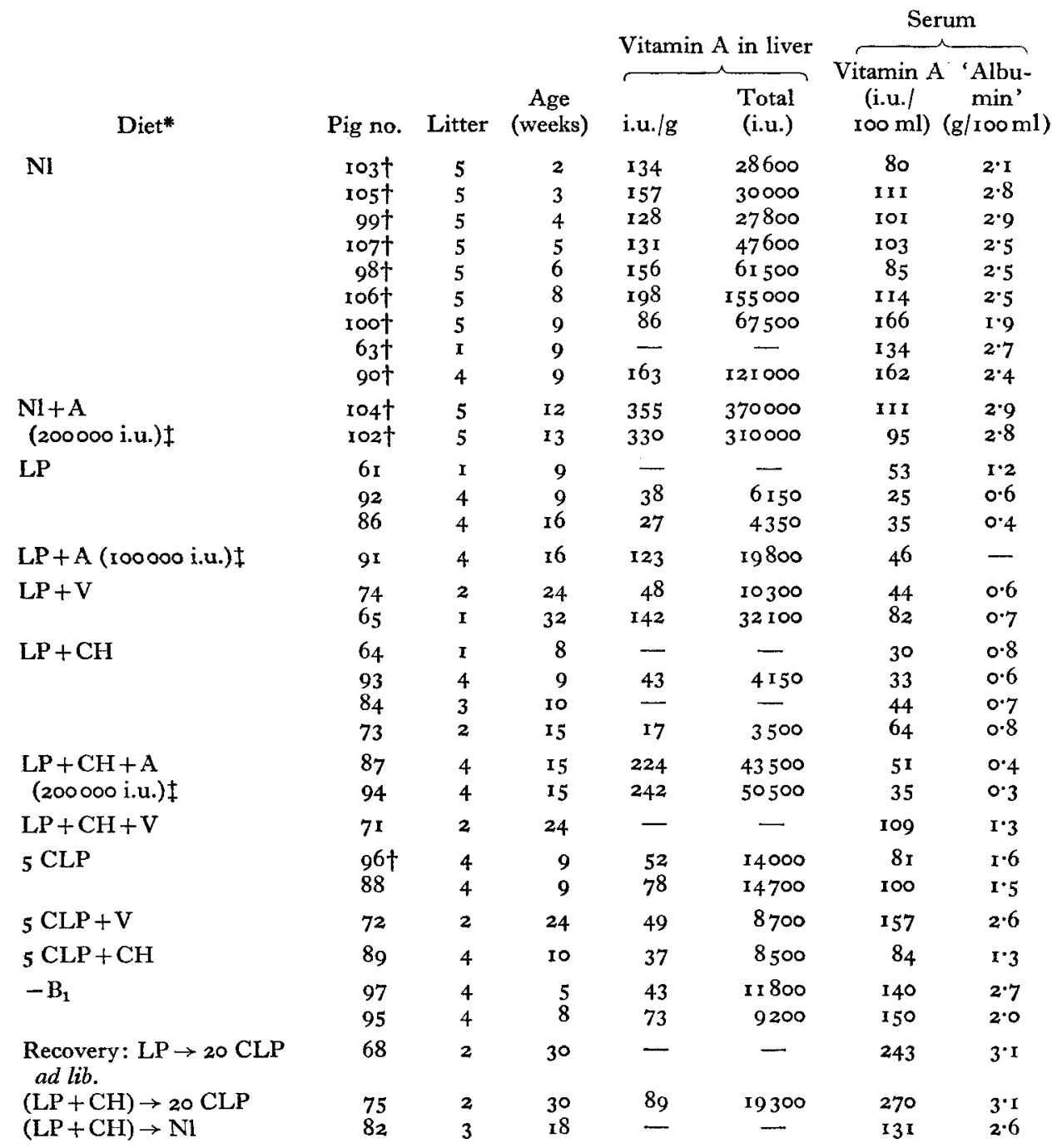

* See Tables I and 2. † Food given ad lib. † Single dose of vitamin A ester.

the liver concentrations were identical, the serum vitamin A content was over four times as high in pig no. 97 as in no. 93 and a difference of corresponding magnitude was found in the 'albumin' fraction of the serum proteins.

Pigs nos. 74 and 72 (litter 2) received isocaloric diets which were identical in all respects except protein content; the liver reserves of vitamin $A$ were similar, yet the animals on the diet higher in protein $(5 \mathrm{CLP}+\mathrm{V})$ had a serum vitamin $\mathrm{A}$ concentra- 
tion approximately four times that of the animal on $\mathrm{LP}+\mathrm{V}$, and the 'albumin' showed corresponding differences.

The serum volume of pig no. 74 was approximately $600 \mathrm{ml}$, and it would have required only $\mathrm{I}$ i.u. $/ \mathrm{ml}$, or a total of 600 i.u., of vitamin $\mathrm{A}$ to raise the serum level to

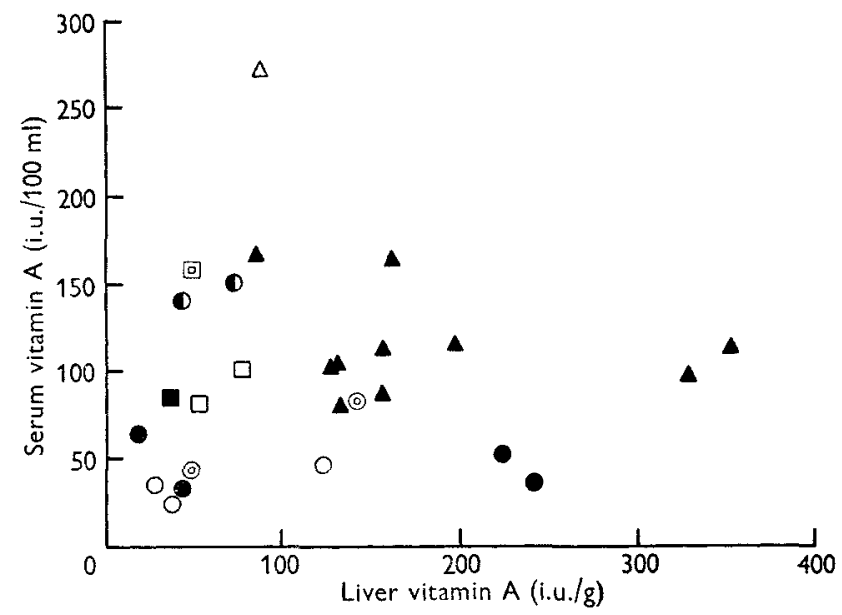

Fig. I. Lack of correlation between the concentration of vitamin $A$ in serum and liver in pigs on diets of varying protein content. Dietary treatment (see p. 232): $\mathrm{O}, \mathrm{LP} ; \mathbf{O}, \mathrm{LP}+\mathrm{CH}$; $\square, 5 \mathrm{CLP} ; \mathbf{E}, 5 \mathrm{CLP}+\mathrm{CH} ; \triangle$, recovery; $\Delta, \mathrm{Nl} ; \mathrm{O},-\mathrm{B}_{1} ; \odot$, 回, additional $\mathrm{B}$ vitamins.

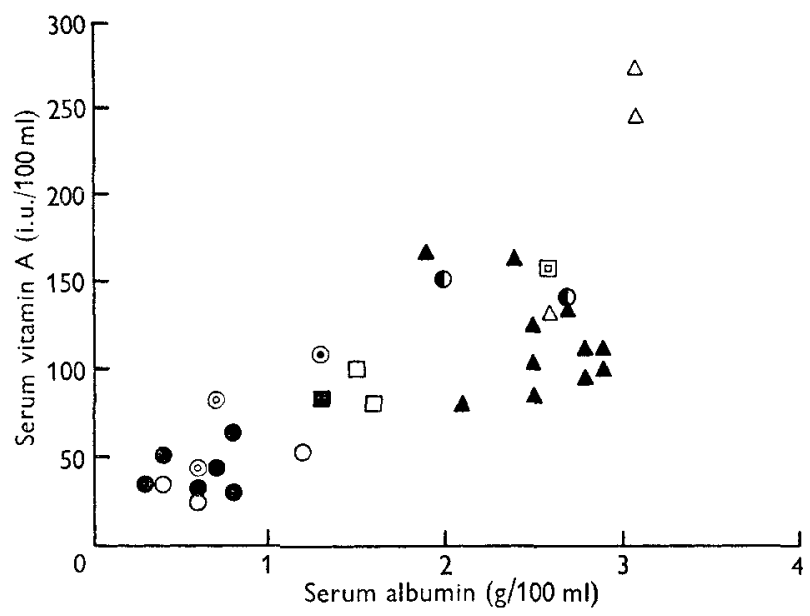

Fig. 2. Correlation between serum vitamin $A$ and serum 'albumin' in pigs on diets of varying protein content. Dietary treatment (see p. 232): O, LP;, $\mathrm{LP}+\mathrm{CH} ; \square, 5 \mathrm{CLP}$; ఐ, $5 \mathrm{CLP}+\mathrm{CH} ; \triangle$, recovery; $\boldsymbol{\Lambda}, \mathrm{NI} ; \mathrm{O},-\mathrm{B}_{1} ; \odot$, $\odot$, 回, additional $\mathrm{B}$ vitamins. $(r=0.76$; $P<0.001$.)

that of pig no. 72. Vitamin A is, of course, found in fluids other than blood, but even if total body fluid were considered, only $5000 \mathrm{i}$.u. would be needed. The withdrawal of these amounts, 600 or 5000 i.u., would have reduced the liver level to 45 or 25 i.u./g, which, although low, is an indication that the reserve should still be sufficient to maintain blood levels. 
The effect on serum vitamin $\mathrm{A}$ of increasing the supply of dietary protein to previously malnourished animals is shown by pigs nos. 75 and 68 (litter 2) and pig no. 82 (litter 3). Pig no. 75 was given the same diet $(\mathrm{LP}+\mathrm{CH})$ as pig no. 93 for 26 weeks, then for 4 weeks was offered an isocaloric quantity of diet $20 \mathrm{CLP}$, the daily intake of carotenoids remaining constant. At death the 'albumin' and vitamin A of the blood were approximately five and eight times as high, respectively, as in pig no. 93, which did not receive any CLP diet, whilst the liver concentration of vitamin A was approximately double. Two other pigs (nos. 68 and 82 ) were offered diets allowing recovery from protein malnutrition and both had unrestricted access to food. Pig no. 68 was transferred from LP (26 weeks) to $20 \mathrm{CLP}$ (4 weeks) and pig no. 82 from $\mathrm{LP}+\mathrm{CH}$ (I4 weeks) to the commercial diet (N1) (4 weeks). The daily intake of carotenoids (pig no. 68) and vitamin A (pig no. 82) was greater after the dietary change. Pig no. 68 on the 20 CLP diet had approximately the same blood values for 'albumin' and vitamin A as pig no. 75 , but those of pig no. 82 were somewhat lower, being similar to those of the normal group.

In the protein-malnourished pigs, all of which had vitamin A in the liver, the concentrations of both serum 'albumin' and serum vitamin A were low. Oral dosing with the vitamin increased the amount in the liver, but had no effect on the concentration in serum so long as the 'albumin' level remained low. Increases in the concentration of serum 'albumin', brought about by raising the dietary protein intake, were accompanied by increases in the vitamin A concentration in the serum.

\section{DISCUSSION}

An interesting comparison can be made between the malnourished pigs described here and those maintained at Cambridge (McCance, 1960). It would appear that, whereas the Cambridge pigs received a small quantity of a diet balanced in protein and carbohydrate, the pigs at Mill Hill received about the same amount of protein diluted with a large quantity of carbohydrate. Vitamin A was provided as cod-liver oil at Cambridge and as carotenoids at Mill Hill. Growth was negligible in both groups of animals. In the Cambridge animals liver stores in the undernourished group were higher than in the normal, and the livers of two pigs fed on a normal diet ad lib. after a period of underfeeding contained 'low normal' amounts of the vitamin. In the Mill Hill pigs the liver reserves of the malnourished animals were below those of littermates receiving extra protein but the same quantity of carotenoids, and were increased in animals which resumed growing after improvement of the diet. Two explanations can be considered: ( $a$ ) that in malnourished states the ability of the animals to convert carotene into vitamin $A$ is greatly reduced and there is therefore less vitamin available for absorption, and $(b)$ that the dilution of the protein in the diet with extra carbohydrate has a profound depressant effect on intestinal absorption.

That a protein-deficient pig receiving a high proportion of carbohydrate in its diet can absorb vitamin A was shown by the higher liver storage in animals given test doses of vitamin A (pigs nos. 87 and 94). When carotenoids are the source of vitamin A, liver stores appear to be markedly reduced in animals on low-protein diets. A protein- 
malnourished pig (no. 92), in spite of poor growth and therefore of low expenditure of vitamin A, had liver stores of only 38 i.u./g, a total of 6150 i.u. Another pig (no. 88), receiving the same amount of carotenoids in isocaloric quantities of a diet with a higher protein content, grew at a faster rate and yet had liver stores of $78 \mathrm{i} . \mathrm{u} . / \mathrm{g}$, a total of I4700 i.u. These observations support the findings of Arnrich \& Pederson (1956) in rats, that, when carotene was the source of vitamin $A$ in low-protein diets, liver stores were lower than normal, but that this effect of low protein was less marked when preformed vitamin A was given.

Low stores of vitamin $\mathrm{A}$ in the livers of protein-malnourished subjects may be due to reduced conversion of carotenoids or impaired absorption or both, but the liver store, provided it remains above a minimum level, is of little importance in regulating the amount of circulating vitamin $\mathrm{A}$. If the dietary intake of carotenoids and vitamin $\mathrm{A}$ were very low, then the reduced conversion and absorption could so reduce body reserves that a frank deficiency might result. This situation is illustrated in a report by Arroyave, Béhar et al. (1959) who describe two groups of patients, one with insignificant and the other with significant liver reserves of vitamin $\mathrm{A}$ on arrival at hospital. In both groups the serum concentration of vitamin A was low. After 8-r 5 days of therapy with skim milk the serum vitamin $A$ in those with the higher liver reserves had risen, owing to 'liberation' of vitamin A from the liver, but the level in the other group remained low. The evidence in the present paper would suggest that in the serum of patients with the higher liver stores but low serum vitamin $A$ levels there was insufficient protein carrier. This deficiency would have been corrected with skim milk and the serum vitamin A level would then have returned towards normal. In the group with the insignificant liver reserves, both carrier and vitamin were deficient and, although the skim milk in the diet would have corrected the serum protein level, the serum vitamin A could not recover until additional vitamin A was made available.

Erwin, Varnell \& Page (1959) noted low serum albumin levels in Holstein heifers that had been fed on a diet deficient in vitamin $A$. When the deficient animals were given vitamin A ester intravenously, the serum albumin level returned to normal at the same time as the serum vitamin A level, 6 days after dosing. As there is no reason to expect that vitamin $\mathrm{A}$ had a direct effect on serum albumin, the probable explanation of these results is that food intake was so reduced on the vitamin A-deficient diet that there occurred protein deficiency and reduction in serum albumin.

Reports such as this arouse speculation as to how far alterations in serum protein may have contributed to the discrepancies between various investigations into the pathology of vitamin A deficiency. There is no doubt that in clinical investigations the effects of protein and vitamin A deficiency, infections and intestinal parasites are difficult, if not impossible, to separate and have led to many apparent anomalies. This is well brought out in the discussion on hypovitaminosis A at the Princeton Conference in 1958. At that meeting McLaren (1958) suggested that any disease or deficiency leading to a reduced serum albumin content might reduce the level of vitamin $\mathrm{A}$ in the blood and thereby produce a deficiency, although the liver still contained reserves of the vitamin. The evidence of the present paper supports this concept. 
Little progress has been made, however, towards deciding which precise protein fraction is responsible for the transport of vitamin A alcohol.

Though the method of electrophoresis used in our work separates clearly the $\alpha_{1}$-globulin of rat and human serums, no such fraction could be separated in any of our pig serums. This observation is in agreement with the work of Nordbring \& Olsson (1957), who could detect $\alpha_{1}$-globulin only in the serum of pigs under 4 days of age, after which time it either disappeared from the serum or merged with the albumin.

The correlation between total 'albumin' and total vitamin A is statistically highly significant; individual variations in the ratio of one to the other are, however, sometimes large. They could be taken to reflect variations within the total 'albumin' of a fraction such as $\alpha_{1}$-globulin, which responds to protein deficiency in the same direction, but not always to the same degree, as serum 'albumin' itself.

The conclusion of Garbers et al. (1960) that $\alpha_{1}$-globulin is the vitamin A carrier rests on the fact that the radioactivity recovered from labelled vitamin $A$ did not coincide with the albumin peak. Interpretations of such evidence must be made with caution, for, as Tata (1960) has shown in work on the binding of radioactive thyroxine, the electrophoretic mobility of the complex formed depends on a number of factors, including the concentration of thyroxine (and by analogy, vitamin A) and even the nature of the supporting medium used for the electrophoresis.

Both vitamin A alcohol and ester are found in serum. The larger part of the vitamin is in the alcohol form and is transported by a protein having an electrophoretic mobility akin to that of albumin, whereas the ester is transported by a lipoprotein. In Fig. 2 the concentration of total vitamin A (alcohol and ester) is compared with that of the 'albumin' fraction, no account being taken of the proportions of the two forms of vitamin. If their proportions varied, then it would be expected that the ratio of vitamin A to 'albumin' would also vary. Vitamin A is transported from the intestine to the liver as the ester (Thompson et al. 1950) and in malnourished animals with a low serum content of vitamin A alcohol, small differences in ester level during absorption would be proportionately large. Blood samples were collected $\mathrm{I} 8 \mathrm{~h}$ after feeding in an effort to keep the vitamin A ester concentration low, but in the protein-malnourished pigs digestion was still proceeding at this time. The concentration of vitamin A ester in such pigs might therefore be expected to be increased and it is in animals with delayed absorption that the ratio of vitamin A to 'albumin' is highest and the discrepancies are greatest.

Whatever the outcome of the search for the particular protein fraction responsible for transporting vitamin A alcohol in the serum, the point of greatest practical importance is that dietary protein deficiency limits the production of the serum protein fraction carrying vitamin A. This effect may lead to a secondary deficiency whose aetiology may bear no relationship to the dietary supply of the vitamin.

\section{SUMMARY}

1. Young pigs were fed on diets of varying protein and vitamin A or carotenoid content. The liver and serum were analysed for vitamin A and the serum for 'albumin' as determined by paper electrophoresis. 
2. Animals on low-protein diets had lower liver stores of vitamin $A$ than animals on diets adequate in protein, which was considered to be due both to impaired conversion of carotenoids and to reduced absorption of vitamin $A$ in the protein-deficient animals.

3. The concentration of vitamin $\mathrm{A}$ in the serum was also reduced in animals on the low-protein diets. It was shown that this decrease was not related to the concentration of the vitamin in the liver.

4. A highly significant correlation $(r=0.76 ; P<0.00 \mathrm{I})$ was found between the concentration of serum vitamin A and that of serum 'albumin'. When the level of serum 'albumin' was reduced in animals on a protein-deficient diet, the serum level of vitamin A was also reduced, irrespective of the concentration of the vitamin in the liver, and serum vitamin $A$ levels of the protein-malnourished animals could not be corrected by dosing with the vitamin alone.

We are indebted to Mr D. B. Bellis of the Unilever, Ltd, Food Research Department, who kindly supplied the pigs used in these experiments. We acknowledge with gratitude the help of our colleagues, too many to name, who have assisted in various ways in the work with pigs. In particular we wish to thank Mr P. G. Ward, now at the East African Institute for Medical Research, for the electrophoretic analysis of the earlier samples of pig serum and for the preservation of serum and liver samples, and Mrs M. Kelley for her patient co-operation in the preparation of the manuscript.

\section{REFERENCES}

Arnrich, L. \& Pederson, D. J. (1956). Fed. Proc. 15, $2 \times 2$.

Arroyave, G., Béhar, M., Wilson, D., Mendez, J. \& Scrimshaw, N. S. (1959). Fed. Proc. I8, 5 I6.

Arroyave, G., Viteri, F., Béhar, M. \& Scrimshaw, N. S. (1959). Amer. F. clin. Nutr. 7, I85.

Braude, R., Foot, A. S., Henry, K. M., Kon, S. K., Thompson, S. Y. \& Mead, T. H. (1941). Biochem. F. 35, 693.

de Loureiro, J. A. (193 I). Arch, pat., Lisboa, 3, 72.

Dzialoszynski, L. M., Mystkowski, E. M. \& Stewart, C. P. (1945). Biochem. F. 39, 63.

Erwin, E. S., Varnell, T. R. \& Page, H. M. (I959). Proc. Soc. exp. Biol., N.Y., roo, 373.

Friend, C. J., Heard, C. R. C., Platt, B. S., Stewart, R. J. C. \& Turner, M. R. (1960). Proc. Nutr. Soc. I9, xxxiv.

Ganguly, J. \& Krinsky, N. I. (1953). Biochem. F. 54, I77.

Garbers, C. F., Gillman, J. \& Peisach, M. (1960). Biochem. F. 75, 124.

Glover, J., Goodwin, T. W. \& Morton, R. A. (1947). Biochem. F. 4r, 97.

Hardwicke, J. ( 1 954). Biochem. F. 57, I66.

Heard, C. R. C., Platt, B. S. \& Stewart, R. J. C. (1958). Proc. Nutr. Soc. r7, xli.

Hume, E. M. \& Krebs, H. A. (I949). Spec. Rep. Ser. med. Res. Coun. no. 264.

Kimble, M. S. (1939). F. Lab. clin. Med. 24, 1055.

Krinsky, N. I., Cornwell, D. G. \& Oncley, J. L. (1958). Arch. Biochem. Biophys. 73, 233.

McCance, R. A. (1960). Brit. F. Nutr. 14, 59.

McLaren, D. S. (1958). Fed. Proc. 17, Suppl. 2, p. I36.

Nordbring, F. \& Olsson, B. (1957). Acta. Soc. Med. Upsalein. 62, 193.

Pett, L. B. \& LePage, G. A. (1940). F. biol. Chem. 132, 585 .

Platt, B. S. \& Miller, D. S. (1959). Proc. Nutr. Soc. 18, vii.

Tata, J. R. (1960). Brit. med. Bull. 16, 142.

Thompson, S. Y., Braude, R., Coates, M. E., Cowie, A. T., Ganguly, J. \& Kon, S. K. (1950). Brit. $\mathcal{F}$. Nutr. 4, 398.

Trowell, H. C., Moore, T. \& Sharman, I. M. (1954). Ann. N.Y. Acad. Sci. 57, 734.

Yudkin, S. (194I). Biochem. F. 35, 55I. 